体力科学(1998) $47,305 \sim 312$

\title{
脂肪負荷後のリポ蛋白トリグリセライドにおよぼす一過性の低強度運勤の影響
}

\author{
中田 雅 朗 ${ }^{1}$ 裴 祥 容 $^{1}$ 宇根かおり ${ }^{1}$ 小関 迪 ${ }^{2}$

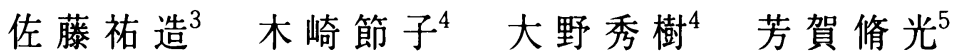

\section{EFFECTS OF A SINGLE PERIOD OF LOW-INTENSITY EXERCISE ON SERUM LIPOPROTEIN TRIACYLGLYCEROL AFTER AN ORAL FAT LOAD}

\author{
Masaaki Nakada, Bae Sang Yong, Kaori Une, Susumu Koseki, Yuzo Sato, \\ TaKako Kizaki, Hideki Ohono and Shukoh Haga
}

\begin{abstract}
From the viewpoint of atherosclerosis prevention, it is important to examine the effects of exercise on the lipoprotein fraction in the postprandial state. The purpose of this study was to investigate the effects of a single period of low-intensity exercise on serum lipoprotein triacylglycerol (TG) after an oral fat load $(50 \mathrm{~g} /$ body surface area) as exogenous TG. Seven normolipidemic men aged $23.1 \pm 1.1$ years (mean $\pm \mathrm{SEM}$ ) took part in two trials. The subjects were all young students at a university graduate school. In the exercise trial $(\mathrm{Ex})$, they exercised for $1.5 \mathrm{~h}$ on a bicycle ergometer at $35-40 \%$ of their maximal oxygen uptake, starting $2 \mathrm{~h}$ after ingestion of the fat, and then rested for a further $2 \mathrm{~h}$. In the control trial $(\mathrm{Co})$, they rested for $5.5 \mathrm{~h}$ after ingestion of the fat. Lipoprotein and lipid levels were measured in venous blood taken during the fasted state and at different intervals between the two trials for $5.5 \mathrm{~h}$ after the fat load. Serum total TG and high-density lipoprotein (HDL) TG decreased significantly in Ex from 3.5 to $5.5 \mathrm{~h}(\mathrm{p}<0.05, \mathrm{p}<0.01)$ in comparison with Co. These results indicate that a single period of low-intensity exercise reduces exogenous serum total TG and HDL-TG.
\end{abstract}

(Jpn. J. Phys. Fitness Sports Med. 1998, $47: 305 \sim 312$ )

key words : low-intensity exercise, exogenous lipoprotein triacylglycerol, atherosclerosis

\section{I. 粕}

動脈硬化症と食後のリポ蛋白代謝は密接に関連 している1)。これは食後血液中に増加するキロ ミクロンレムナント (chylomicron remnant : CMR)および超低比重リポ蛋白 (very low density lipoprotein：VLDL)レムナントなどのトリグリセ ライド(triacylglycerol：TG)に富むリポ蛋白は動 脈硬化惹起性 (atherogenic) に作用する, という考
えに基づいているが，冠動脈疾患患者を対象とし て経口脂肪負荷後, キロミクロンレムナントのク リアランスの遅延やリポ蛋白トリグリセライドの 増大がみられた報告がある ${ }^{2)}$ 。この結果から, 動 脈硬化症と食後のリポ蛋白代謝は密接に関連して いると考えられ，食後のリポ蛋白代謝過程の検討 は動脈硬化予防の観点から重要であると考えられ る.

また、リポ蛋白代謝過程をより詳細に把握する

\footnotetext{
${ }^{1}$ 筑波大学大学院

テ305-8574 つくば市天王台1-1-1

2 筑波記念病院

テ300-2622 つくば市要1187-299

3 名古屋大学総合保健体育科学センター T464-8601 名古屋市千種区不老町

${ }^{4}$ 防衛医科大学校衛生学 于359-8513 所沢市並木3-2

5 筑波大学体育科学系 テ305-8574つくば市天王台1-1-1
}

Graduate School of Tsukuba University

Tsukuba Memorial Hospital

Research center of Health, Physical Fitness and sport, Nagoya University

Department of Hygiene, National Defence Medical college

Institute of Health and Sport Sciences, University of Tsukuba 
ためにリポ蛋白粒子，すなわち，リポ蛋白分画に 対する疾病および運動の影響を検討した報告がな されている ${ }^{3 \sim 8)}$. 疾病の影響としては，冠動脈疾 患でかつ高脂血症である患者は経口脂肪負荷後, large CM-R (Sf 60-400)が増加し, small-VLDL は 滅少したと報告されている5)。高比重りポ蛋白 (high density lipoprotein：HDL) 分画に関しては 冠動脈疾患患者において, large HDL 粒子，つま り $\mathrm{HDL}_{2 \mathrm{~b}}$ レベルが冠動脈硬化の進行度と有意な 負の相関を示すことが知られている4)。また，低 HDL コレステロール (cholesterol：C)レベルで高 脂血症のものは HDL 粒子が TG に富んでおり， 低 HDL-C レベルと高脂血症を共有すると食後の キロミクロンレムナントを優先的に蓄積すると報 告されている6).

さらに，運動の影響として長距離ランナーは主 に $\mathrm{HDL}_{2 \mathrm{a}}$ および $\mathrm{HDL}_{2 \mathrm{~b}}$ を主に含む $\mathrm{HDL}$ 粒子レ ベルが高く, dense LDL レベルが低かったことも 報告されており ${ }^{8)}$, 一過性の長時間運動でも運動 後においても $\mathrm{HDL}_{2}$ 粒子のコレステリルエステ ル (cholesteryl ester : CE) が相対的に増加し, TG は滅少したことが示されだ)。健常男性において 85\%HRmax 強度で50分の自転車運動を 3 回/週の トレーニングの結果, 6 週間後には HDL-TG が 有意に減少し, HDL-C および HDL-CE が増加 し，また $\mathrm{HDL}_{2} / \mathrm{HDL}_{3}$ が增加したという報告があ $ろ^{7)}$.これらの結果は運動トレーニングの持続の 結果, HDL の粒子組成に変化が生じたことを示 している.

以上のように,リポ蛋白脂質に対する疾病およ び運動の影響が検討されているが，リポ蛋白脂質 に対する運動の影響に関する報告はほとんど内因 性脂質の研究であり，外因性のリポ蛋白脂質の代 謝過程に関して検討した報告はほとんどなされて いない，つまり，食後高脂血症に対する運動の影 響をリポ蛋白脂質分画での代謝過程から検討した 報告はみあたらない.

そこで, 高脂血症という状態に対する運動の影 響をリポ蛋白分画での代謝過程から検討すること は, 動脈硬化症の予防という観点から意義あるこ とと考えられる．本研究では食後最も変動する
TGに着目し，外因性脂質除去過程におけるリポ 蛋白 TGにおよほす一過性の低強度運動の影響 を検討することを目的とした。

\section{II. 方法}

\section{1. 被検者}

健常な成人男性 7 名 (平均年齡 $23.1 \pm 1.1$ 歳, BMI 21.9土1.3)を対象とした。被検者はすべて 体育専攻の大学院生であったが定期的に運動を行 なっていないものであった。これらの被検者の血 清脂質レベルは正常で，かつ肥満傾向や，契煙お よび薬物等の服用はなかった。研究に際しては主 旨を説明し，全ての被検者から書面により承諾を 得た. 身体特性は表 1 に示した.

Table 1. Characteristics of the sbjects $(n=7)$.

\begin{tabular}{|c|c|c|}
\hline Age & (yrs) & $23.1 \pm 1.1$ \\
\hline Height & $(\mathrm{cm})$ & $171.6 \pm 6.4$ \\
\hline Weight & $(\mathrm{kg})$ & $64.4 \pm 4.6$ \\
\hline BMI & & $21.9 \pm 1.3$ \\
\hline$\%$ Fat & $(\%)$ & $11.3 \pm 1.6$ \\
\hline Ora fat mass & (g) & $88.7 \pm 4.7$ \\
\hline$\dot{\mathrm{V}} \mathrm{O}_{2} \max$ & $(\mathrm{ml} / \mathrm{kg} / \mathrm{min})$ & $57.1 \pm 5.1$ \\
\hline
\end{tabular}

Data are means $\pm S$. D.

$\mathrm{BMI}$ : body mass index, $\dot{\mathrm{V}} \mathrm{O}_{2} \max$ : maximal oxygen uptake.

\section{2. 最大酸素摄取量の測定}

最大酸素摄取量 $\left(\mathrm{V}_{2} \max \right)$ は自転車エルゴメー 夕(モナーク社製)で，多段階漸増負荷法により測 定した.

3. 経口脂肪負荷

経口脂肪負荷量は体表面積 (BSA) 当たり $50 \mathrm{~g}$ (平均 $88.7 \pm 4.7 \mathrm{~g}$ ) とし, 脂肪は森永乳業(侏)の生 クリーム (成分: 無脂乳固形分 $4.0 \%$, 植物性脂肪 分 $44.0 \%$, 乳化剂, ph 調整剂, 香料, カロチン 色素)を使用した。

\section{4. 研究の手順}

研究の手順は図 1 に示した。被検者には本実験 当日 2 日前から運動を, 前日はアルコール摃取を 禁止した，運動を実施した実験期間を「Exercise trial (以下 Ex )」, 運動を実施しない実験期間を $\ulcorner$ Control trial (以下 Co)」とし, 両実験間は 2 週 


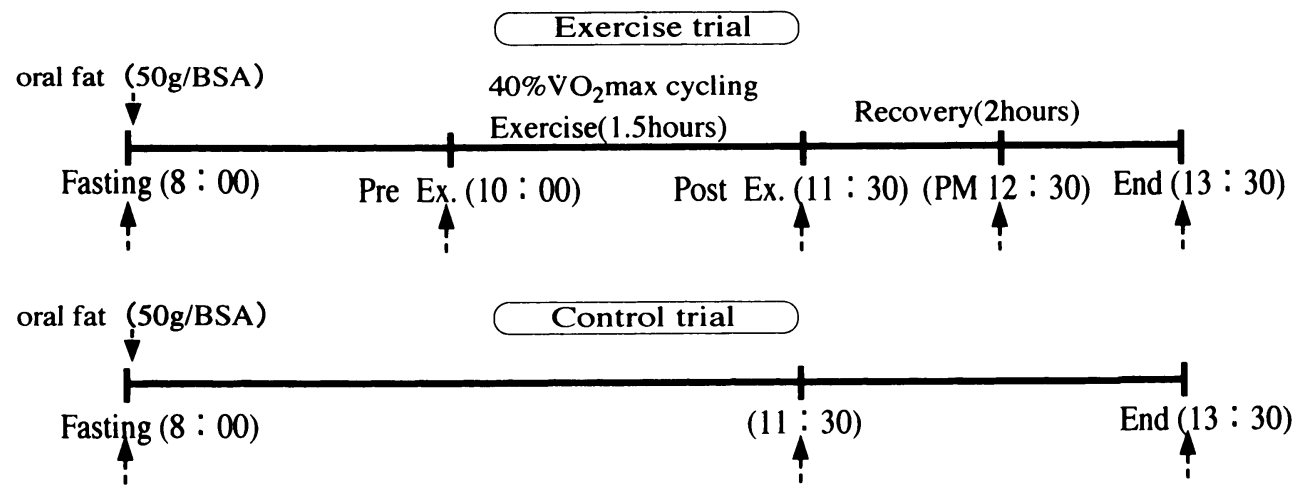

Fig. 1. Study procedure.

間以上の間隔をとり実施した。

a) Exercise trial における採血および採気の 手順

夕食後 12 時間空腹を保った後, 採血は 1）午前 8 時 (空腹時)に行い, その直後に経口脂肪負荷を 行い,その 2 時間経過後の 2) 運動前 ( 2 時間後), および 3） 35 ～ $40 \% \mathrm{~V}_{2} \max$ 強度による自転車工 ルゴメーターによるペダリング運動 1 時間半完遂 後 ( 3 時間半後), 運動終了後から 4) 1 時間後 ( 4 時間半後)および 5) 2 時間後 ( 5 時間半後)の計 5 回行った。なお, 本研究での運動強度および時 間は Hardman たちの研究 ${ }^{9)}$ を参考にした。

採気は座位安静で 3 分間, 運動中は10分毎に後 半の 1 分間行った.また, 心拍数の記録は採気時 間中に実施した。

b) Control trialにおける採血および採気の 手順

採血は12時間空腹後の 1) 空腹時 (朝 8 時)に行 い, その直後に経口脂肪負荷を行い, その 2） 3 時間半後および 3) 5 時間半後の計 3 回行った. なお，2つの trial 中それぞれミネラルウォー ター $(350 \mathrm{ml})$ の飲水は許可した.

\section{5. 血液分析項目}

ヘモグロビン $(\mathrm{Hb})$, ヘマトクリット值, リポ 蛋白脂質分画定量および遊離脂肪酸 (NEFA)を血 液分析項目とした。

\section{6. 統計処理}

統計の処理は，対応のある $\mathrm{t}$-検定により比較 検定を実施し，有意水準は $5 \%$ 未満とした.
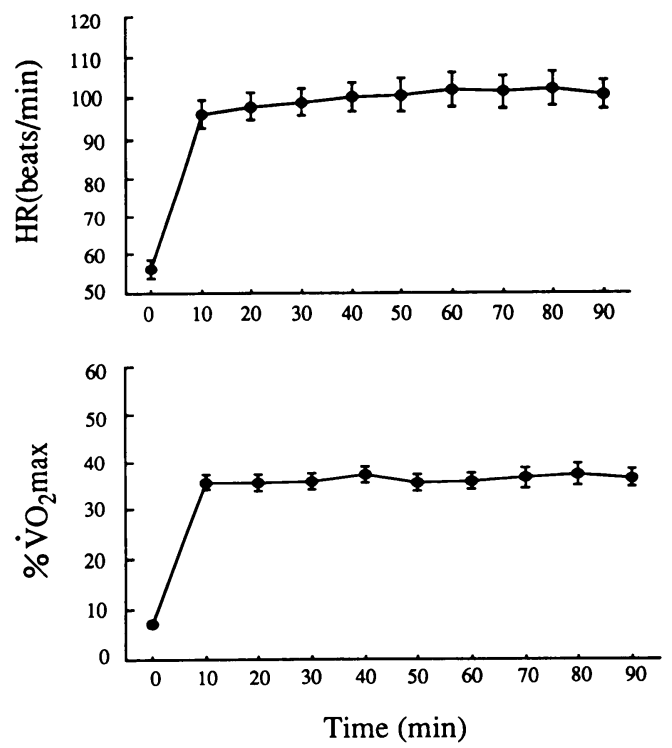

Fig. 2. Heart rate (upper panel) and $\% \mathrm{~V}_{2} \max$ (lower panel) during exercise.

Data are means \pm SEM.

\section{III. 結}

果

1. 運動中の心拍数 (HR) および酸素摂取量 $\left(\% \dot{\mathrm{V}} \mathrm{O}_{2} \max \right)$ の変動

心拍数および \% $\mathrm{VO}_{2} \max$ の変動を図 2 に示し た．運動中の心拍数の変動は95.9 $3.4 \sim 102.0 \pm$ 4.1 beats $/ \mathrm{min}$ であり, \% $\mathrm{V}_{2} \max は 35.1 \pm 1.8$ $38.6 \pm 1.7 \%$ あっった.

\section{2. 血清リポ蛋白トリグリセライドの変動}

総トリグリセライド (total-triacylglycerol：T$\mathrm{TG})$ の変動を図 3 に示した. $\mathrm{Ex}$ および Co とも 

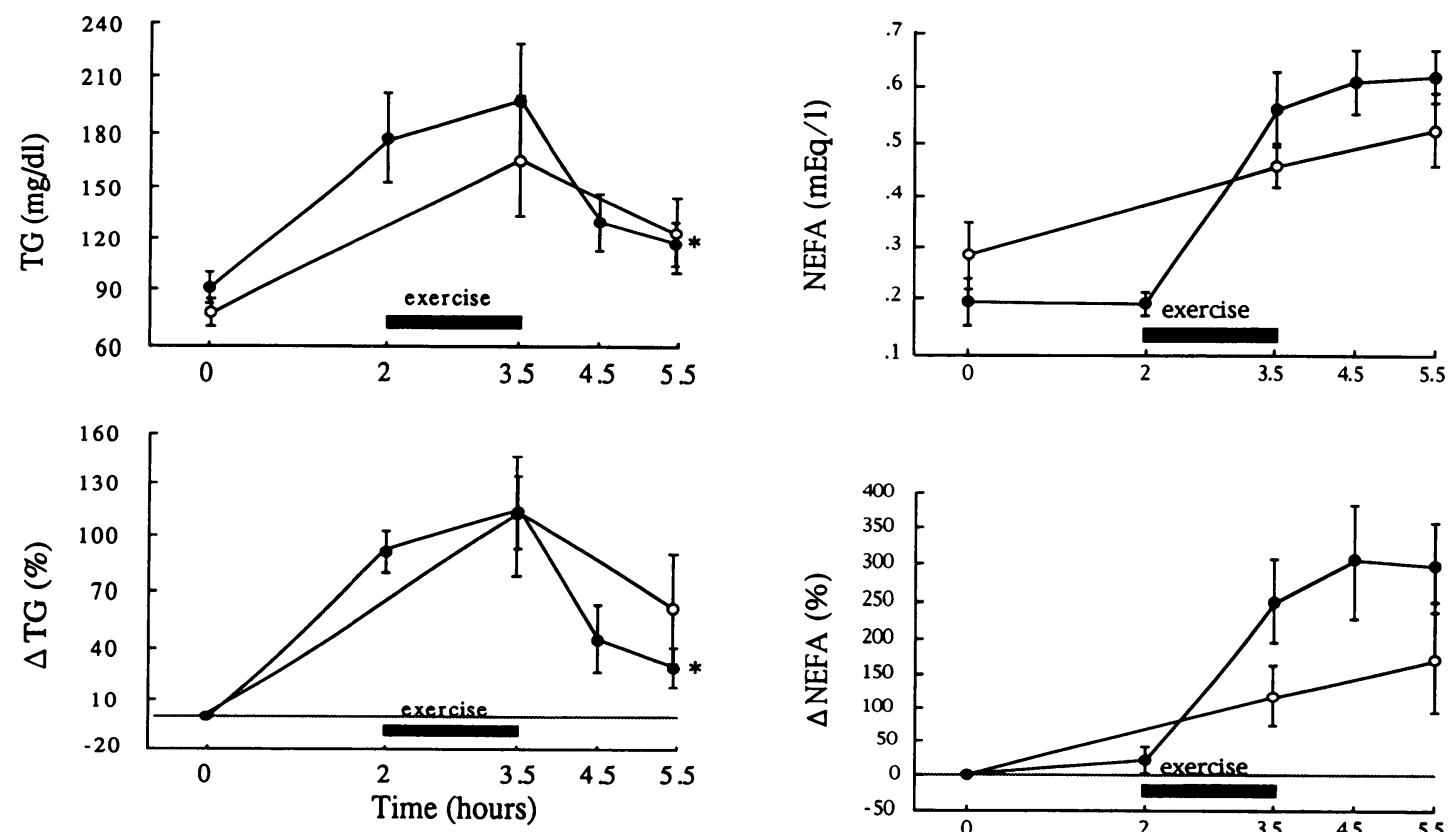

Fig. 3. Concentrations of serum total-triacylglycerol during exercise $(O)$ and control $(O)$ trials. Data are means \pm SEM.

$* \mathrm{p}<0.05$ compared with control in the changes from $3.5 \mathrm{~h}$ to $5.5 \mathrm{~h}$.
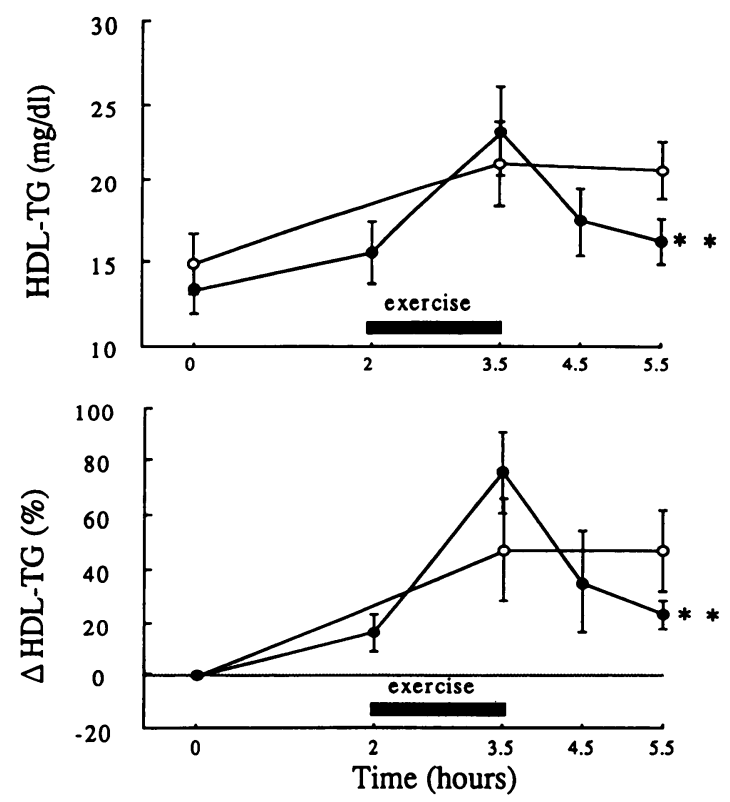

Fig. 4. Concentrations of serum high density lipoprotein triacylglycerol during exercise $(O)$ and control $(\bigcirc)$ trials. Data are means \pm SEM. $* * \mathrm{p}<0.01$ compared with control in the changes from $3.5 \mathrm{~h}$ to $5.5 \mathrm{~h}$

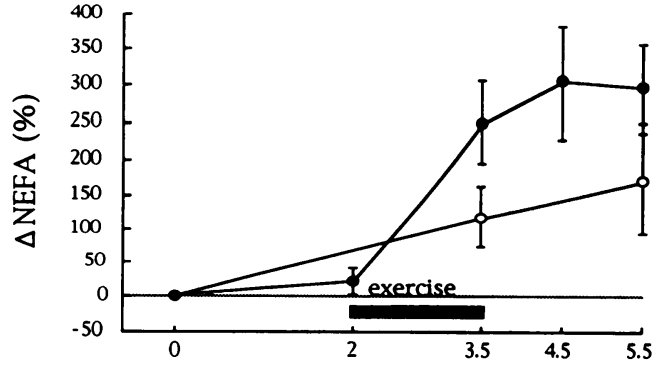

Time (hours)

Fig. 5. Concentrations of plasma non-esterified fatty acid during exercise $(O)$ and control $(O)$ trials. Data are means \pm SEM.

に空腹時から脂肪負荷 3 時間半後にかけては, そ れぞれ113.9土20.7\%および $112.0 \pm 34.8 \%$ とほほ 同じ程度増加したが, その 2 時間後までの低下率 は Ex の場合で $37.5 \pm 5.4 \%$ と Co の場合の $24.8 \pm$ $3.1 \%$ に比べて有意に大きかった $(\mathrm{p}<0.05)$.

高比重リポ蛋白トリグリセライド (high density lipoprotein triacylglycerol : HDL-TG)の変動を図 4 に示した. 脂肪負荷 3 時間半後から 2 時間後ま での低下率は Ex の場合で $28.0 \pm 3.7 \%$ と Co の場 合のー3.9土10.4\%に比べて有意に大きかった $(\mathrm{p}<0.01)$.

3. 血清遊離脂肪酸 (non-esterified fatty acid :

NEFA)の変動

血清遊離脂肪酸の変動を図 5 に示した。脂肪負 荷 3 時間半後から5時間半後にかけて, Ex の場合 において高い傾向にあったが, 有意差はなかった。

\section{N. 考察}

本研究の結果, 一過性の低強度運動後 T-TG 
は有意に隇少したが，これは食後の低強度運動が 高 TG 血症を抑えるということを示し，他の研 究と同様の結果を得た ${ }^{9,10)}$ 。これは, 運動中に消 費した筋内 TG を補充するために，リポ蛋白 TG が筋に取り込まれたことにより生じたことを示し ているのかもしれない.この見解を支持するメカ ニズムとして考えられることは，運動による筋り ポ蛋白リパーゼ(LPL) 活性の増大，およびそれに 伴う筋内 TG 備蓄の補充である. LPL 活性に関 する研究について, Schlierf たち ${ }^{10)}$ は食事摄取1 時間半後に, $40 \% \dot{\mathrm{VO}}_{2} \max$ 強度の運動 1 時間半後 では運動を行っていないコントロールの場合と比 較し，血漿 LPL 活性が有意に増大したことを示 した。この LPL 活性の增大は本研究においても 運動後の血清 TG レベルの低下を促した理由と して考えられる.しかしながら，他の研究 ${ }^{11)}$ は1時間の運動後でも LPL 活性は増大しないこと が報告されている。このことは LPL 活性が増大 しなくても血清 TG レベルを低下させる何らか の原因が考えられる。 その要因として，TG に富 むりポ蛋白が受容体により能動的に細胞内に取り 込まれ，供給されることであり，それはVLDL 受容体が心臓, 筋肉および脂肪細胞などのエネル ギー代謝に活発な組織に局在することからも考え られることである.

本研究の $35 \sim 40 \% \mathrm{VO}_{2} \max$ 強度で 1 時間半の運 動において，運動中のエネルギー基質としては運 動初期にはグリコーゲン, 次いで糖質, 120分ぐ らいより脂質中のエネルギーであるが本研究は Romijn $^{12)}$, Cyle ${ }^{13)}$ たちの研究結果を考慮すると, 主に血槳 FFA および筋内 $\mathrm{TG}$ であると推測でき る.つまり，運動中には主に脂肪が利用されてい たと考えられるが，T-TG はEx および Co とも に脂肪負荷 3 時間半後 (運動直後)までほほ同程度 増加している.Hardman たち ${ }^{9)} も$ 本研究と同様に, 運動実施の有無にもかかわらず食事攝取 3 時間後 では差はないが，その 1 時間後に運動を行った場 合には血清 TG 濃度が有意に隇少することを報 告している。これは,リポ蛋白循環での血清 TG 代謝が運動中ではなく，運動後に重要な役割を果 たすことを示している8 ${ }^{8.10}$. すなわち，血清
TG は運動後の代謝過程において大きく変動する ものであり，リポ蛋白代謝における運動の影響を 検討するにはその点に注目すべきであると考え る.

次に本研究の結果, HDL-TG は運動後に有意 に減少した. $\mathrm{HDL}_{2}$ 粒子 (large HDL 粒子) は冠動

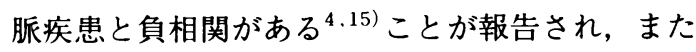
$\mathrm{HDL}_{2}$ 粒子でも $\mathrm{HDL}_{2}-\mathrm{C}$ は冠動脈疾患と負相関が ある ${ }^{16)}$ ，高脂血症である患者の HDL 粒子は TG に富んでいるが，これは肝性リパーゼによる加水 分解をより受けやすい HDL 粒子が増加すること により, $\mathrm{HDL}_{2}$ から $\mathrm{HDL}_{3}$ への形成が起こり, 最 終的には循環血液中から HDL の除去が生じる6) と報告されている，さらに健常男性において最高 心拍数の $85 \%$ 強度で50分の自転車運動を週に 3 回 のトレーニングの結果, 6 週間後には HDL-TG が有意に滅少し, HDL-C および HDL-CE が増加

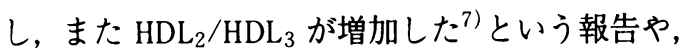
$30 \mathrm{~km}$ のクロスカントリーランニング後において $\mathrm{HDL}_{2}$ 粒子のコレステリルエステルが相対的に増 加し, TG は隇少したと示され, 一過性の運動後 においても HDL 粒子の組成変化が起こってい $る^{3)}$ と報告されている．以上のような見解から， 本研究で得られた運動後の HDL-TG の有意な減 少は一過性の影響であるが, 抗動脈硬化的な現象 を示唆しているかもしれない.

本研究は動脈硬化進展の予防という観点から, 食後に運動を行い, 次の食事までには少しでも血 中の TG の蓄積を抑えるという 1 日のわずか 5 時間半という短時間の研究であるが, リポ蛋白に 対する運動の遅延効果の検討もなされている. Annuzzi たち ${ }^{14)}$ は 77\%HRmax 強度による 3 時間 の運動を行ない, その 2 日後では血清 $\mathrm{T}-\mathrm{TG} お$ よび T-C の減少， 3 日後では T-C の減少を示し ている. Dufauxたち(7) は血中乳酸濃度が 4 $\mathrm{mmol} / \mathrm{L}$ に達した值の $75 \%$ の強度で 3 時間のト レッドミル走行後, 2 日間は血清 T-TG および $\mathrm{T}-\mathrm{C}$ の滅少, $\mathrm{HDL}_{2}-\mathrm{C}$ の増加が生じているが, 4 日後にはその効果は消失したと報告している。つ まり,リポ蛋白におよほす一過性の運動の影響 の検討は 1 日だけではなく，3 日間にわたる検討 
も必要であるかもしれない.しかしながら， Annuzzi たち(14)や Dufauxたち ${ }^{17)}$ の研究のような 3時間もの運動は通常の運動処方の考え方からす れば実施は困難であり，リポ蛋白に対する運動時 間および強度に対する直後および遅延の影響に関 してはなお十分な検討が必要であると考えられ る.

結論として，一過性の低強度運動が外因性のリ ポ蛋白 TG レベルの低下を促進させ, HDL-TG を滅少させた。

\section{V. 要的}

本研究は血中脂質レベルが正常で, かつ肥満傾 向のない健常な成人男性を対象とし，外因性脂質 除去過程におけるリポ蛋白トリグリセライドにお よほす一過性の低強度運動の影響を検討すること を目的とした。

結果は以下の通りである.

1）一過性の低強度運動により外因性のリポ蛋 白 TGレベルの低下が促進し、T-TG および HDL-TG の運動後の有意な隇少が観察された.

これらの結果は, 一過性ではあるが抗動脈硬化的 な現象を示唆しているかもしれない.

2) 本研究は 1 日のわずか 5 時間半という短時 間の研究であるが, 食後高脂血症に対して, 動脈 硬化の予防という観点から運動の影響を検討する ためには，長時間の研究も必要であると考えられ る、また,どのような運動強度および一回の運動 時間を与えたのかも考慮されなければならい。そ れらに影響するリポ蛋白粒子のサイズおよび組成 に関しては未解明の点が多く，今後さらに詳細な 検討が必要であると思われる.

（受理日 平成10年 2 月 6 日）

\section{文}

\section{献}

1) Zilversmit, D. B. Atherogenesis : a postprandial phenomenon. Circulation. (1979), 60, 473-85.

2) Patsch, J. R., Miesenbock, G., Hopferwieser, T., Muhlberger, V., Knapp, E., Dunn, J. K., Gooto, A. M. Jr., and Patsch, W. Reration of triglyceride metabolism and coronary artery disease : studies in the postprandial state. Arteriosclerosis and thrombosis., (1992), 12, 1336-1345.
3) Frey, I., Baumstark, M. W., and Berg, A. Acute and delayed effects of prolonged exercise on serum lipoproteins I. Composition and distribution of high density lipoprotein subfractions. Eur. J. Appl. Physiol., (1993), 66, 521-525.

4) Johansson, J., Carlson, L. A., Laandou, C., and Hamsten, A. High density lipoproteins and coronary atherosclerosis - a strong inverse relation with the argest particles is confined to normotriglyceridemic patients-. Arteriosclerosis and thrombosis., (1991), 11, 174-182.

5) Karpe, F., Steiner, G., Olivecrona, T., Carlson, L. A., and Hamsten, A. Metabolism of triglyceride-rich lipoproteins during alimentary lipemia. J. Clin. Invest., (1993), 91, 748-758.

6) Omeara, N. M., Lewis, G. F., Cabana, V. G., Iverius, P. H., Getz, G. S., and Polonsky, K. S. Role of basal triglyceride and high density lipoprotein in determination of postprandial lipid and lipoprotein responses. J. Clin. Endocrinol. Metab., (1992), 75. 465-471.

7) Stubbe, I., Hansson, P., Gustafson, A., and NilssonEhle, P. Plasma lipoproteins and lipolytic enzyme activities during endurance training in sedentary men : changes in high-density lipoprotein subfractions and composition. Metabolism., (1983), 43, 836841.

8) Williams, P. T., Krauss, R. M., Wood, P. D., Lindgren, F. T., Giotas, C., and Vanizan, K. M. Lipoprotein subfractions of runners and sedentary men. Metabolism., (1986), 35, 45-52.

9) Hardman, A. E., and Aldred, H. E. Walking during the postprandial period decreases alimentary lipaemia. Journal of Cardiovascular Risk (1995), 2. 71-78

10) Schlierf, G., Dinsenbacher, A., Kather, H., Kohlmeier, M., and Haberbosch, W. Mitigation of alimentary lipemia by postprandial exercisephenomena and mechanisms.-Metabolism., (1987). 36, 726-730.

11) Lithell, H., Orlander, J., and Schele, R. Changes in lipoprotein lipase activity and lipid stores in human skeletal muscle with prolonged heavy exercise. Acta Physiol Scand., (1979), 107, 257-261.

12) Romijin, J. A., Coyle, E. F., Sidossis, L. S., Gastaldelli, A., Horowizt, J. F., Endert, E., and Wolf, R. R. Regulation of endgenous fat and carbohydrate metabolism in ralation to exercise intensity and duration. Am. J. Physiol., (1993), 265 (Endocrinol Metab 28), E 380-E 391.

13) Colyle, E. F. Substrate utilization during exercise in active people. Am. J. Clin. Nutr., (1995), 61, 968 S-79S.

14) Annuzzi, G., and Jansson, E., Kaijser, L., Holmquist, L., Carlson, L. A. Increased removal rate of exogenous triglycerides after prolonged exercise in man : time 
course and effect of exercise duration. Metabolism., (1987), 36, 438-443.

15) Ballantyne, F., Clark, R. S., Simpson, H. S., and Ballantyne, D. High density and low density lipoprotein subfractions in survivors of myocardial infarc. tion and in control subjects. Metabolism., (1982), 31, 433-437.
16) Miller, N. E. Associations of high density lipoprotein subclasses and apoproteins with ischaemic heart disease and coronary atherosclerosis. Am. Heart. J. (1987), 113, 589-597.

17) Defaux, B., Order, U., Muller, R., and Hollman, W Delayed effects of prolonged exercise on serum lipoproteins. Metabolism., (1986), 35, 105-109. 